$\underline{\text { Supplementary Material for: }}$

\title{
Push-Pull [2]Pseudorotaxanes. Electronic Control of Threading by Switching ON/OFF an Intramolecular Charge Transfer
}

\author{
Sarah J. Vella, Jorge Tiburcio, James W. Gauld and Stephen J. Loeb*
}

Preparation of 4-((4-N,N'-dimethylamino)phenyl)pyridine: A 3-necked round bottom flask was charged with DMF $(200 \mathrm{~mL})$ and THF $(100 \mathrm{~mL})$. To this 4-(N,N-dimethylamino)phenylboronic acid (2.00 g, $0.0121 \mathrm{~mol})$, 4-bromopyridine hydrochloride (2.36 g, $0.0121 \mathrm{~mol})$ and sodium carbonate $(7.71 \mathrm{~g}, 0.0727 \mathrm{~mol})$ were added and the solution degassed for $1 \mathrm{~h}$. Tetrakis(triphenylphosphine)palladium(0) was added and the solution degassed an additional $30 \mathrm{~min}$. The reaction was refluxed for $24 \mathrm{~h}$ then cooled to room temperature and the solvents removed by evaporation. Water was added to the resulting residue and the product was extracted three times with $\mathrm{CH}_{2} \mathrm{Cl}_{2}$. The organic portions were combined, dried with anhydrous $\mathrm{MgSO}_{4}$, filtered and taken to dryness. This yielded [4-(4- $N, N^{\prime}$-dimethylamino)phenyl]pyridine as a pale yellow solid $(2.28 \mathrm{~g}, 0.0115 \mathrm{~mol}$, 95\%). ${ }^{1} \mathrm{H}$ NMR $\left(\mathrm{CD}_{3} \mathrm{CN}\right): \delta(\mathrm{ppm}) 8.50\left(\mathrm{~d}, 2 \mathrm{H},{ }^{3} \mathrm{~J}=6.2 \mathrm{~Hz}\right), 7.64\left(\mathrm{~d}, 2 \mathrm{H},{ }^{3} \mathrm{~J}=8.9 \mathrm{~Hz}\right)$, $7.54\left(\mathrm{~d}, 2 \mathrm{H},{ }^{3} \mathrm{~J}=6.2 \mathrm{~Hz}\right), 6.83\left(\mathrm{~d}, 2 \mathrm{H},{ }^{3} \mathrm{~J}=8.9 \mathrm{~Hz}\right), 2.99(\mathrm{~s}, 6 \mathrm{H})$. ESI-MS: $m / z$ [M-OTf] ${ }^{+}$ calc. 339.9331, found 339.9341 .

Preparation of 4'-((4- $N, N$-dimethylamino)phenyl)pyridiniumethylbromide triflate: 4 '-(4- $N, N$-dimethylaminophenyl)pyridine $(0.750 \mathrm{~g}, 0.00378 \mathrm{~mol})$ was dissolved in 1,2 dibromoethane $(50 \mathrm{~mL})$ and refluxed for $24 \mathrm{~h}$. The reaction was cooled to room temperature and the resulting precipitate filtered using a Büchner funnel. The precipitate was washed with $\mathrm{CH}_{2} \mathrm{Cl}_{2}$. This afforded the product (bromide salt) as yellow powder $(1.19 \mathrm{~g}, 0.00306 \mathrm{~mol}, 82 \%)$. This was anion exchanged to the triflate salt by the addition of a slight excess of $\operatorname{NaOTf}(a q) .{ }^{1} \mathrm{H}$ NMR (bromide salt in $\left.\mathrm{D}_{2} \mathrm{O}\right): \delta(\mathrm{ppm}) 8.44\left(\mathrm{~d}, 2 \mathrm{H},{ }^{3} \mathrm{~J}\right.$ $=6.9 \mathrm{~Hz}), 8.02\left(\mathrm{~d}, 2 \mathrm{H},{ }^{3} \mathrm{~J}=6.9 \mathrm{~Hz}\right), 7.81\left(\mathrm{~d}, 2 \mathrm{H},{ }^{3} \mathrm{~J}=9.0 \mathrm{~Hz}\right), 6.85\left(\mathrm{~d}, 2 \mathrm{H},{ }^{3} \mathrm{~J}=9.0 \mathrm{~Hz}\right)$, $2.96(\mathrm{~s}, 6 \mathrm{H}) 4.74\left(\mathrm{t}, 2 \mathrm{H},{ }^{3} \mathrm{~J}=5.7 \mathrm{~Hz}\right), 3.85\left(\mathrm{t}, 2 \mathrm{H},{ }^{3} \mathrm{~J}=5.7 \mathrm{~Hz}\right) .{ }^{1} \mathrm{H}$ NMR (triflate salt in $\left.\mathrm{CD}_{3} \mathrm{CN}\right): \delta(\mathrm{ppm}) 8.38\left(\mathrm{~d}, 2 \mathrm{H},{ }^{3} \mathrm{~J}=7.1 \mathrm{~Hz}\right), 8.09\left(\mathrm{~d}, 2 \mathrm{H},{ }^{3} \mathrm{~J}=7.1 \mathrm{~Hz}\right), 7.89\left(\mathrm{~d}, 2 \mathrm{H},{ }^{3} \mathrm{~J}=9.2\right.$ $\mathrm{Hz}), 6.87\left(\mathrm{~d}, 2 \mathrm{H},{ }^{3} \mathrm{~J}=9.2 \mathrm{~Hz}\right), 3.09(\mathrm{~s}, 6 \mathrm{H}) 4.72\left(\mathrm{t}, 2 \mathrm{H},{ }^{3} \mathrm{~J}=5.9 \mathrm{~Hz}\right), 3.89\left(\mathrm{t}, 2 \mathrm{H},{ }^{3} \mathrm{~J}=5.9\right.$ Hz). ESI-MS: $m / z$ [M-OTf] ${ }^{+}$calc. 339.9331, found 339.9341 .

Preparation of Bis-(4'-((4-N,N-dimethylamino)phenyl)pyridinium)ethane triflate, [1][OTf $]_{2}: 4^{\prime}-(4-N, N$-dimethylaminophenyl)pyridiniumethylbromide triflate $(0.850 \mathrm{~g}$, $0.00187 \mathrm{~mol})$ and 4 '-(4- $N, N$-dimethylamino)phenylpyridine $(0.740 \mathrm{~g}, 0.00373 \mathrm{~mol})$ were dissolved in acetonitrile $(50 \mathrm{~mL})$ and refluxed for 7 days. The reaction was cooled to room temperature and the solvent evaporated. The residue was dissolved in $\mathrm{CH}_{2} \mathrm{Cl}_{2}$ and the resulting precipitate was filtered and washed with $\mathrm{CH}_{2} \mathrm{Cl}_{2}$. This afforded a yellow powder the product as the bromide salt $(1.19 \mathrm{~g}, 0.00306 \mathrm{~mol}, 82 \%)$ which was subsequently anion exchanged to the triflate salt. $(2.28 \mathrm{~g}, 0.0115 \mathrm{~mol}, 95 \%) .{ }^{1} \mathrm{H}$ NMR (triflate salt in $\left.\mathrm{CD}_{3} \mathrm{CN}\right): \delta(\mathrm{ppm}) 8.29\left(\mathrm{~d}, 4 \mathrm{H},{ }^{3} \mathrm{~J}=7.1 \mathrm{~Hz}\right), 8.05\left(\mathrm{~d}, 4 \mathrm{H},{ }^{3} \mathrm{~J}=7.1 \mathrm{~Hz}\right), 7.88$ $\left(\mathrm{d}, 4 \mathrm{H},{ }^{3} \mathrm{~J}=9.1 \mathrm{~Hz}\right), 6.87\left(\mathrm{~d}, 4 \mathrm{H},{ }^{3} \mathrm{~J}=9.1 \mathrm{~Hz}\right), 4.88(\mathrm{~s}, 4 \mathrm{H}), 3.10(\mathrm{~s}, 12 \mathrm{H})$. ESI-MS: $\mathrm{m} / z$ $[\mathrm{M}-\mathrm{OTf}]^{+}$calc. 573.2142, found 573.2118. (see ${ }^{1} \mathrm{H}$ and ${ }^{13} \mathrm{C}$ NMR spectra below) 
Preparation of 3-((4-N,N'-dimethylamino)phenyl)pyridine: A 3-necked round bottom flask was charged with DMF $(200 \mathrm{~mL})$ and THF $(100 \mathrm{~mL})$. To this 4 - $(N, N$-dimethylamino)phenylboronic acid (2.00 g, $0.0121 \mathrm{~mol}), 3$-bromopyridine $(1.92 \mathrm{~g}, 0.0121 \mathrm{~mol})$ and sodium carbonate $(7.71 \mathrm{~g}, 0.0727 \mathrm{~mol})$ were added and the solution degassed for $1 \mathrm{~h}$. Tetrakis(triphenylphosphine)palladium(0) was added and the solution degassed an additional $30 \mathrm{~min}$. The reaction was refluxed for $24 \mathrm{~h}$ then cooled to room temperature and the solvents removed by evaporation. Water was added to the resulting residue and the product was extracted three times with $\mathrm{CH}_{2} \mathrm{Cl}_{2}$. The organic portions were combined, dried with anhydrous $\mathrm{MgSO}_{4}$, filtered and taken to dryness. The isolated solid was recrystallized from diethylether to yield the product as a beige solid $(2.14 \mathrm{~g}, 0.0108 \mathrm{~mol}$, $89 \%){ }^{1} \mathrm{H}$ NMR $\left(\mathrm{CD}_{3} \mathrm{CN}\right): \delta(\mathrm{ppm}) 8.79(\mathrm{~s}, 1 \mathrm{H}), 8.43\left(\mathrm{~d}, 1 \mathrm{H},{ }^{3} \mathrm{~J}=4.7 \mathrm{~Hz}\right), 7.90\left(\mathrm{~d}, 1 \mathrm{H},{ }^{3} \mathrm{~J}\right.$ $=7.9 \mathrm{~Hz}), 7.54\left(\mathrm{~d}, 2 \mathrm{H},{ }^{3} \mathrm{~J}=6.8 \mathrm{~Hz}\right), 7.34\left(\mathrm{dd}, 1 \mathrm{H},{ }^{3} \mathrm{~J}=4.7 \mathrm{~Hz},{ }^{3} \mathrm{~J}=7.9 \mathrm{~Hz}\right), 6.85\left(\mathrm{~d}, 2 \mathrm{H},{ }^{3} \mathrm{~J}\right.$ $=6.8 \mathrm{~Hz}), 2.97(\mathrm{~s}, 6 \mathrm{H})$. ESI-MS: $\mathrm{m} / z$ [M-OTf] ${ }^{+}$calc. 339.9331, found 339.9341.

Preparation of Bis-(3'-((4-N,N-dimethylamino)phenyl)pyridinium)ethane triflate, [4][OTf] $2:$ 3'-((4-N,N-dimethylamino)phenyl)pyridine (1.00 g, $0.00504 \mathrm{~mol})$ and 1,2dibromoethane $(0.190 \mathrm{~g}, 0.00101 \mathrm{~mol})$ were dissolved in acetonitrile $(50 \mathrm{~mL})$ and refluxed for 4 days. The precipitate that formed was isolated by filtration which afforded the product (bromide salt) as a pale yellow powder $(1.19 \mathrm{~g}, 0.00306 \mathrm{~mol}, 82 \%)$. This was subsequently anion exchanged to the triflate salt using $\operatorname{NaOTf}(a q)(2.28 \mathrm{~g}, 0.0115 \mathrm{~mol}$, $95 \%) .{ }^{1} \mathrm{H}$ NMR (triflate salt in $\left.\mathrm{CD}_{3} \mathrm{CN}\right): \delta(\mathrm{ppm}) 8.84(\mathrm{~s}, 2 \mathrm{H}), 8.70\left(\mathrm{~d}, 2 \mathrm{H},{ }^{3} \mathrm{~J}=8.0 \mathrm{~Hz}\right.$ ), $8.33\left(\mathrm{~d}, 2 \mathrm{H},{ }^{3} \mathrm{~J}=6.0 \mathrm{~Hz}\right), 7.97\left(\mathrm{dd}, 1 \mathrm{H},{ }^{3} \mathrm{~J}=6.0 \mathrm{~Hz},{ }^{3} \mathrm{~J}=8.0 \mathrm{~Hz}\right), 7.60\left(\mathrm{~d}, 4 \mathrm{H},{ }^{3} \mathrm{~J}=9.1 \mathrm{~Hz}\right)$, $6.88\left(\mathrm{~d}, 4 \mathrm{H},{ }^{3} \mathrm{~J}=9.1 \mathrm{~Hz}\right), 5.09(\mathrm{~s}, 4 \mathrm{H}), 3.04(\mathrm{~s}, 12 \mathrm{H})$. ESI-MS: $\mathrm{m} / \mathrm{z}[\mathrm{M}-\mathrm{OTf}]^{+}$calc. 573.2142, found 573.2155. (see ${ }^{1} \mathrm{H}$ and ${ }^{13} \mathrm{C}$ NMR spectra below) 
${ }^{1} \mathrm{H}$ NMR spectrum $\left(\mathrm{CD}_{3} \mathrm{CN}\right)$ of $[\mathbf{1}][\mathrm{OTf}]_{2}$

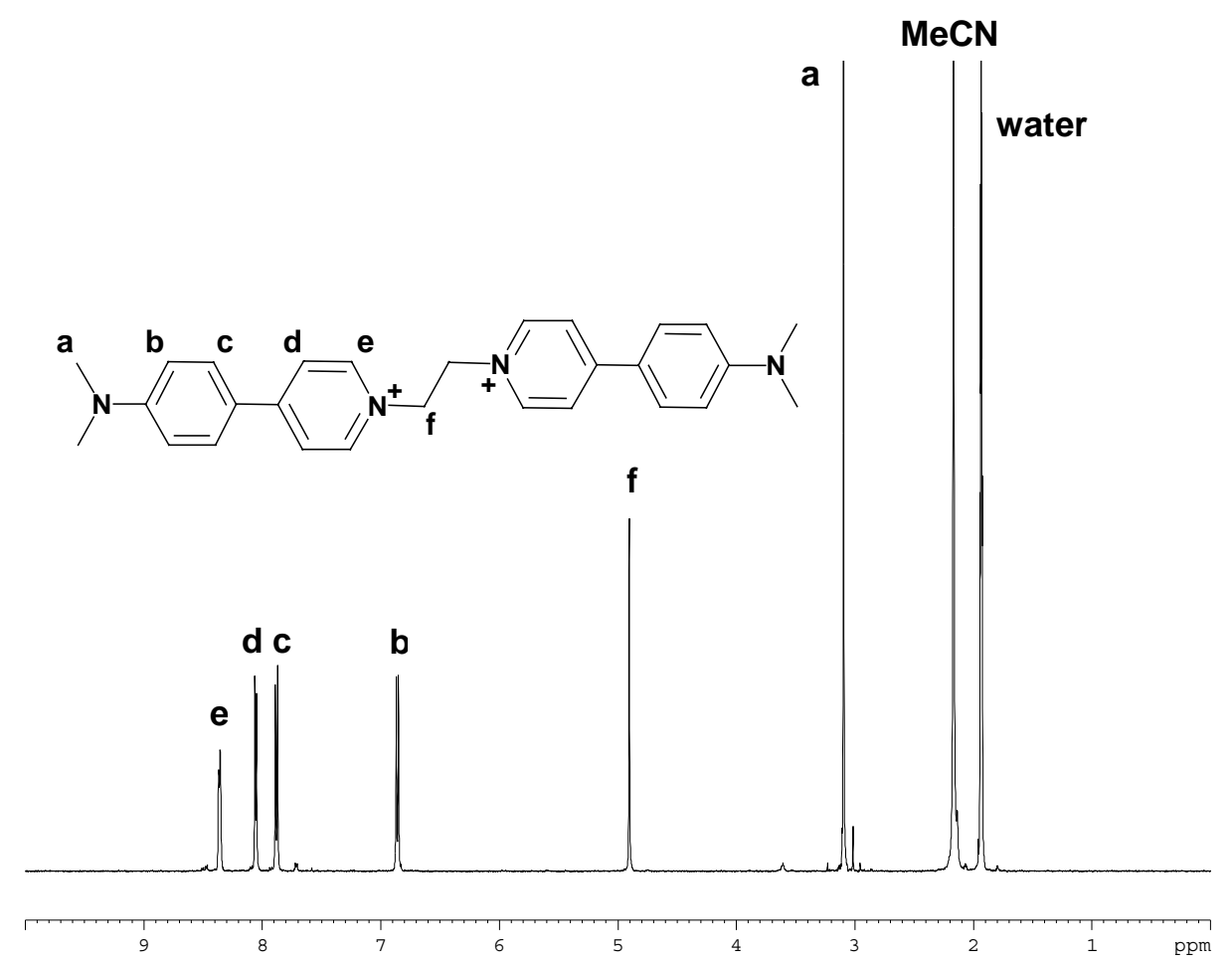

${ }^{13} \mathrm{C}$ NMR spectrum $\left(\mathrm{CD}_{3} \mathrm{CN}\right)$ of $[1][\mathrm{OTf}]_{4}$

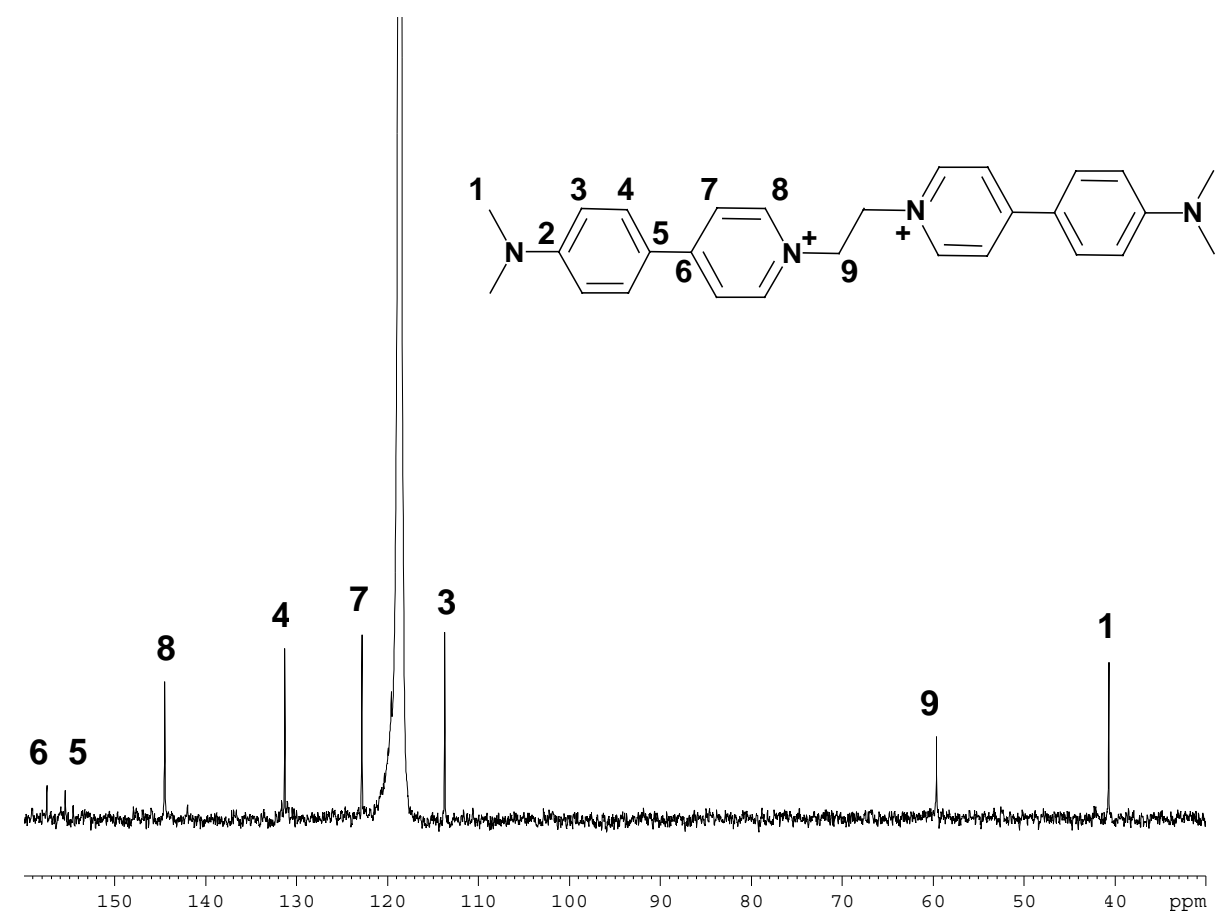



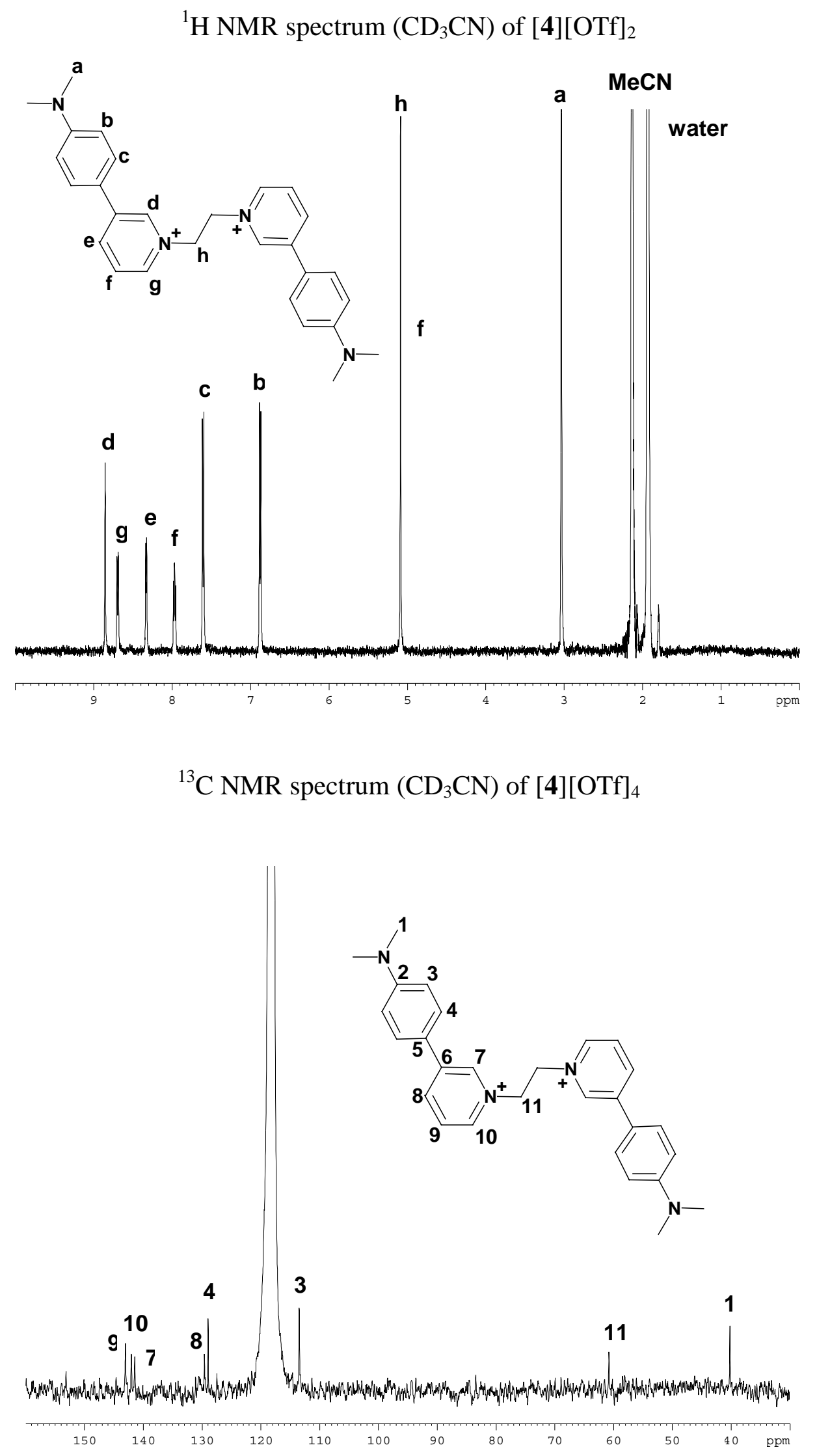
${ }^{1} \mathrm{H}$ NMR spectrum $\left(\mathrm{CD}_{3} \mathrm{CN}\right)$ of a 1:1 mixture of $[\mathbf{1}][\mathrm{OTf}]_{2}$ and DB24C8.

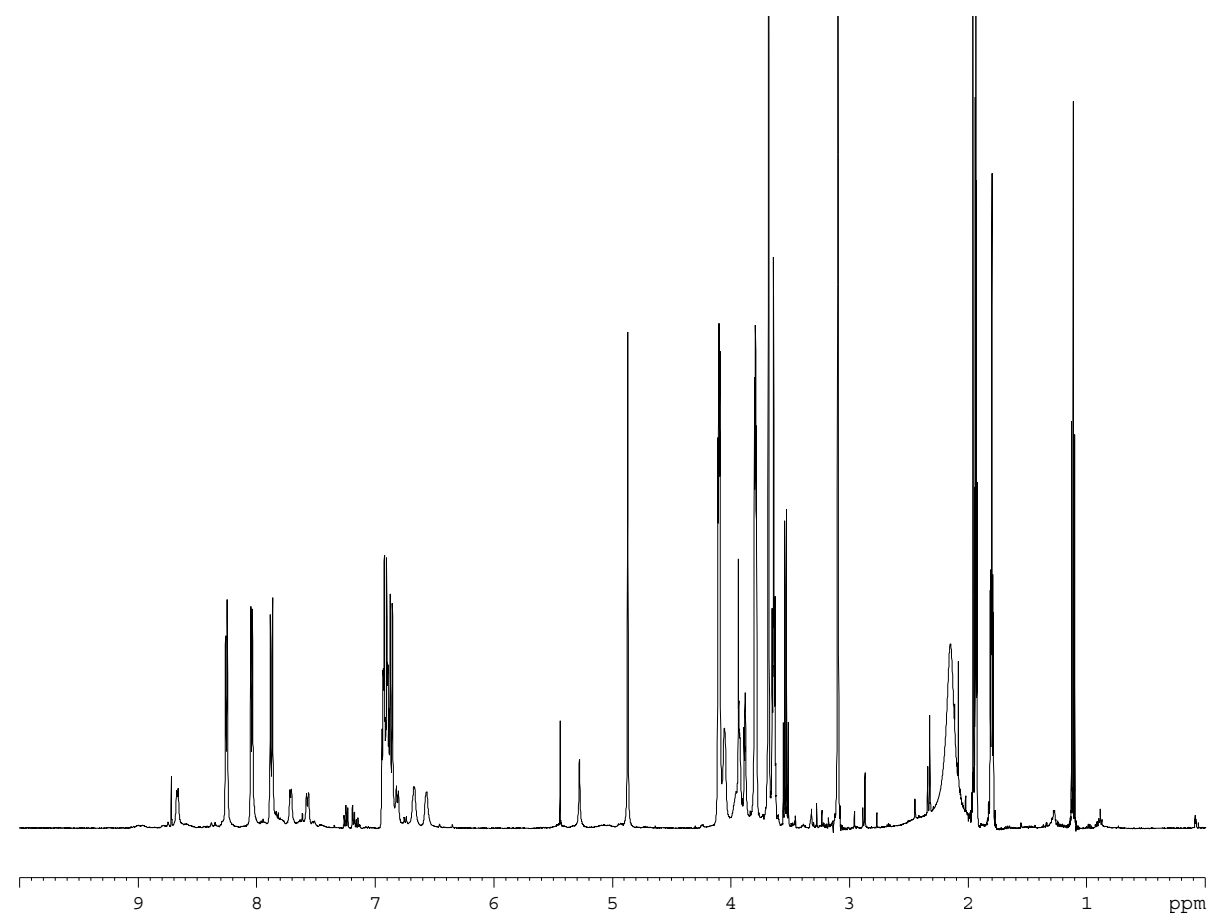

${ }^{1} \mathrm{H}$ NMR spectrum $\left(\mathrm{CD}_{3} \mathrm{CN}\right)$ of a 1:1 mixture of [2][OTf $]_{4}$ and DB24C8.

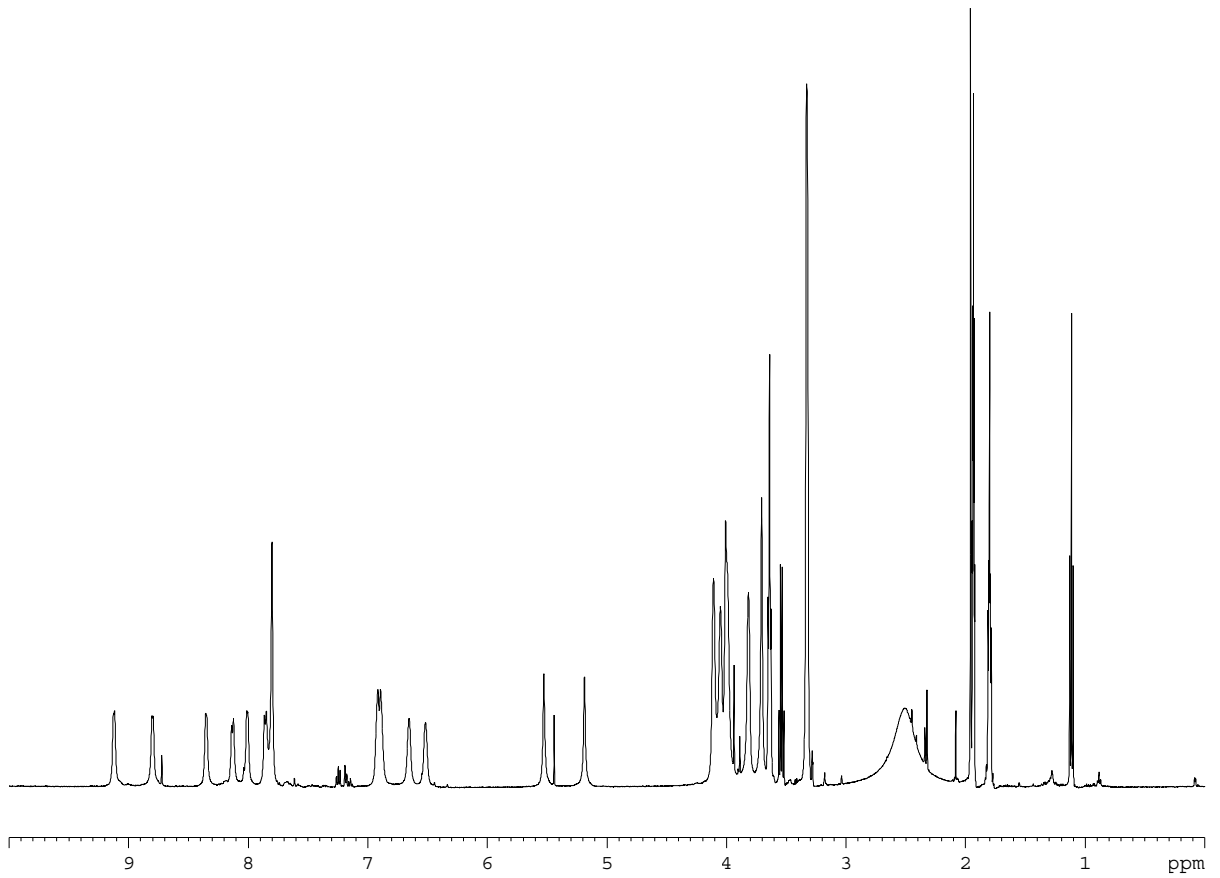


${ }^{1} \mathrm{H}$ NMR spectrum $\left(\mathrm{CD}_{3} \mathrm{CN}\right)$ of a 1:1 mixture of $[4][\mathrm{OTf}]_{2}$ and DB24C8.

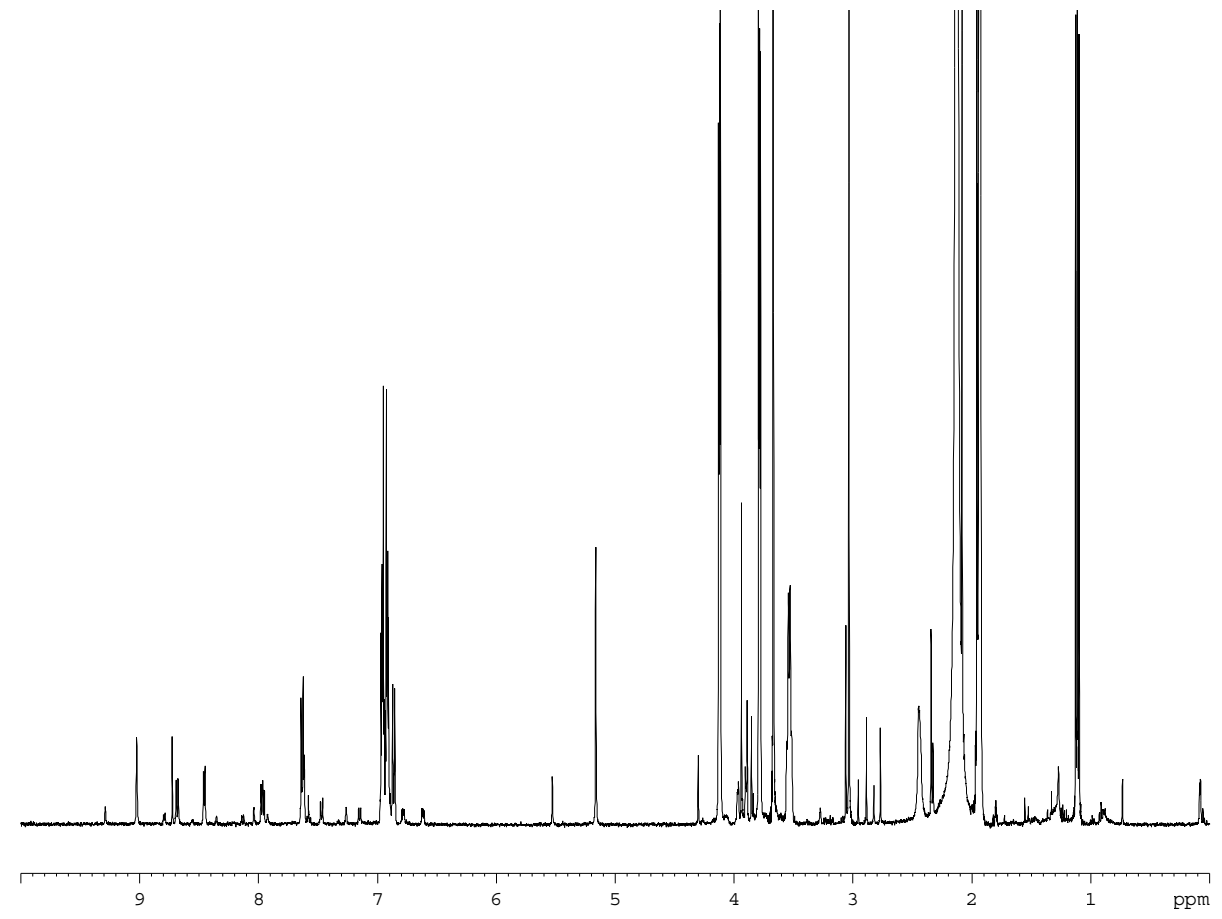

${ }^{1} \mathrm{H}$ NMR spectrum $\left(\mathrm{CD}_{3} \mathrm{CN}\right)$ of a 1:1 mixture of $[\mathbf{5}][\mathrm{OTf}]_{4}$ and $\mathbf{D B 2 4 C 8}$.

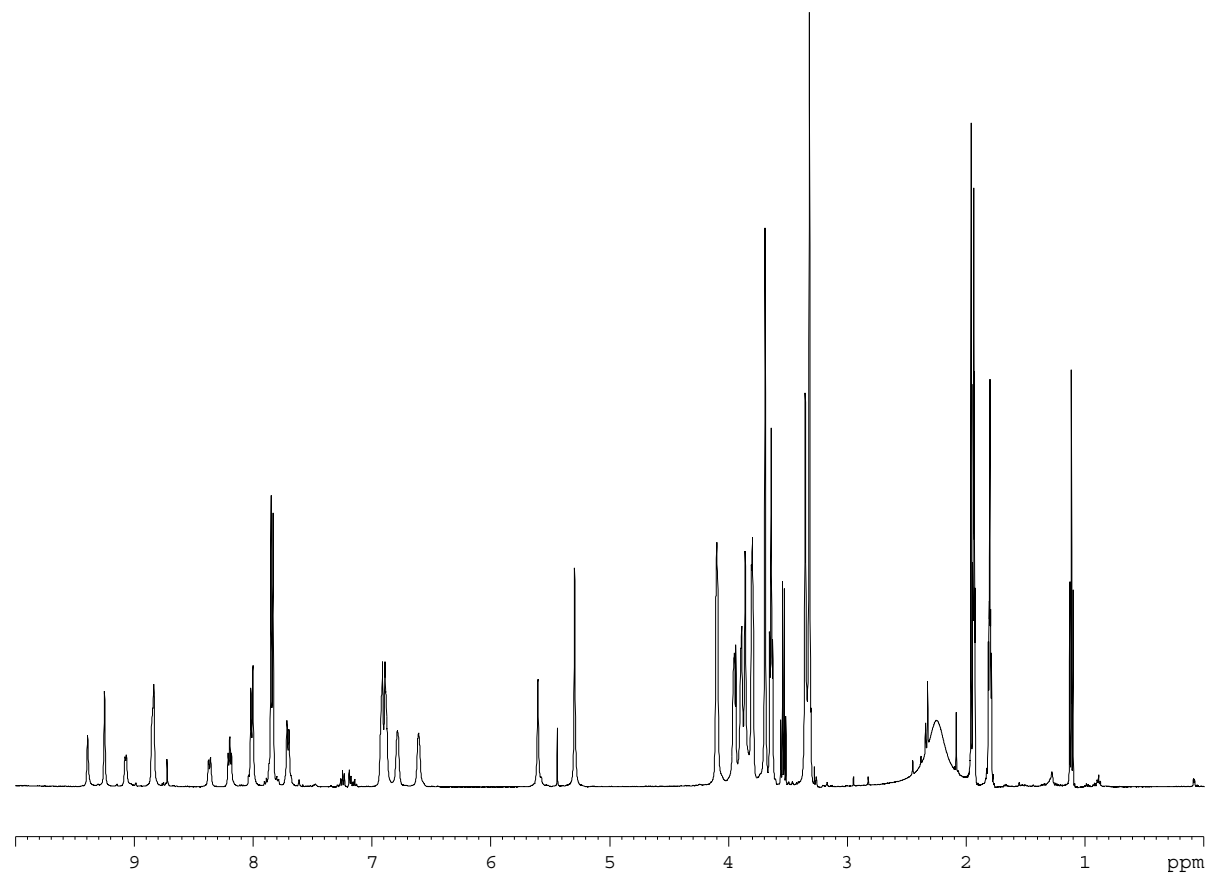




\section{Computational Methods}

All calculations were performed using the Gaussian 03 suite of programs. ${ }^{1}$ Optimized gas-phase structures were obtained using the density functional theory (DFT) method B3LYP, a combination of Becke's three-parameter hybrid exchange functional, ${ }^{2-3}$ as implemented ${ }^{4}$ in Gaussian 03, ${ }^{1}$ and the correlation functional of Lee, Yang and Parr, ${ }^{5}$ in conjunction with the 6-31G(d,p) basis set. The HOMO and LUMO orbitals are shown at the 0.032 isodensity value.

\section{References}

1. Frisch, M. J.; Trucks, G. W.; Schlegel, H. B.; Scuseria, G. E.; Robb, M. A.; Cheeseman, J. R.; Montgomery, Jr., J. A.; Vreven, T.; Kudin, K. N.; Burant, J. C.; Millam, J. M.; Iyengar, S. S.; Tomasi, J.; Barone, V.; Mennucci, B.; Cossi, M.; Scalmani, G.; Rega, N.; Petersson, G. A.; Nakatsuji, H.; Hada, M.; Ehara, M.; Toyota, K.; Fukuda, R.; Hasegawa, J.; Ishida, M.; Nakajima, T.; Honda, Y.; Kitao, O.; Nakai, H.; Klene, M.; Li, X.; Knox, J. E.; Hratchian, H. P.; Cross, J. B.; Bakken, V.; Adamo, C.; Jaramillo, J.; Gomperts, R.; Stratmann, R. E.; Yazyev, O.; Austin, A. J.; Cammi, R.; Pomelli, C.; Ochterski, J. W.; Ayala, P. Y.; Morokuma, K.; Voth, G. A.; Salvador, P.; Dannenberg, J. J.; Zakrzewski, V. G.; Dapprich, S.; Daniels, A. D.; Strain, M. C.; Farkas, O.; Malick, D. K.; Rabuck, A. D.; Raghavachari, K.; Foresman, J. B.; Ortiz, J. V.; Cui, Q.; Baboul, A. G.; Clifford, S.; Cioslowski, J.; Stefanov, B. B.; Liu, G.; Liashenko, A.; Piskorz, P.; Komaromi, I.; Martin, R. L.; Fox, D. J.; Keith, T.; Al-Laham, M. A.; Peng, C. Y.; Nanayakkara, A.; Challacombe, M.; Gill, P. M. W.; Johnson, B.; Chen, W.; Wong, M. W.; Gonzalez, C.; and Pople, J. A.; Gaussian 03, Gaussian, Inc., Wallingford CT, 2004.

2. Becke, A. D. J. Chem. Phys. 1993, 98, 1372.

3. Becke, A. D. J. Chem. Phys. 1993, 98, 5648.

4. Stephens, P. J.; Devlin, F. J.; Chabalowski, C. F.; Frisch, M. J. J. Phys. Chem. 1994, 98, 11623.

5. Lee, C.; Yang, W.; Parr, R. G. Phys. Rev. B 1998, 37, 785. 
LUMO for $\mathbf{1}^{2+}$

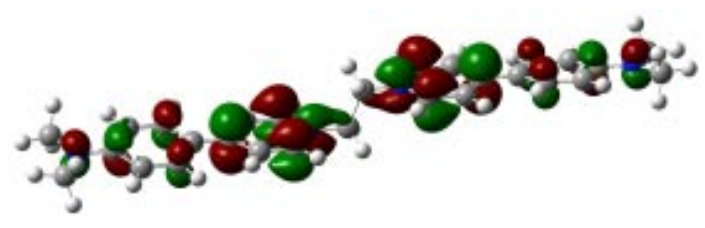

LUMO for $\mathbf{2}^{4+}$

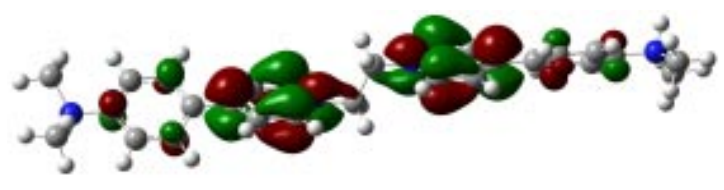

LUMO for $\mathbf{3}^{2+}$

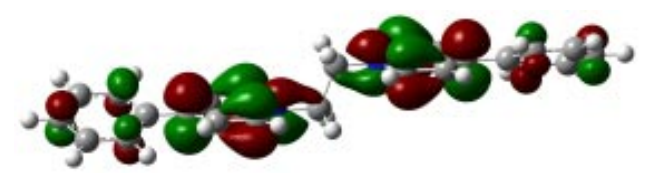

HOMO for $\mathbf{1}^{2+}$

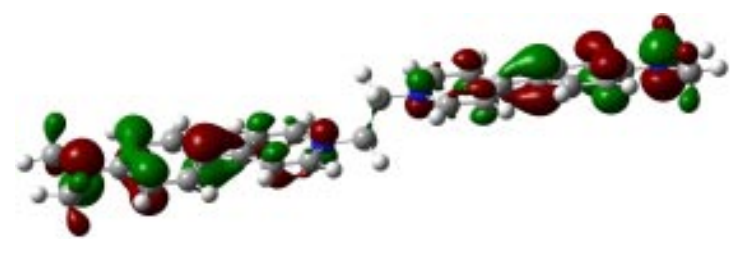

HOMO for $2^{4+}$

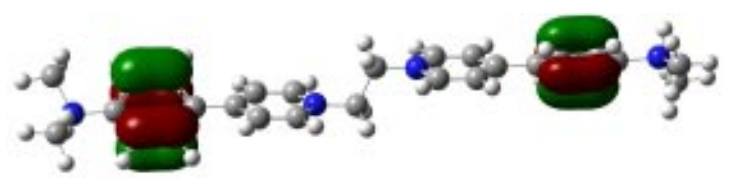

HOMO for $\mathbf{3}^{2+}$

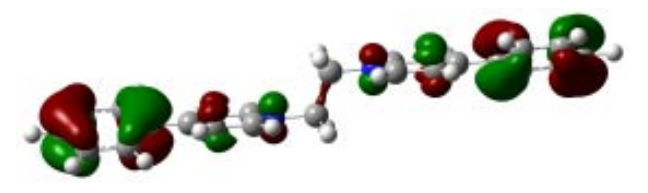

